\title{
KADAR HARA NPK TANAMAN KELAPA SAWIT PADA BERBAGAI TINGKAT KEMATANGAN TANAH GAMBUT DI PERKEBUNAN KELAPA SAWIT PT. PENITI SUNGAI PURUN KABUPATEN MEMPAWAH
}

\author{
NUTRIENT LEVELS OF OIL PALM NPK AT DIFFERENT STAGES PEAT SOIL \\ DECOMPOSITION IN OIL PALM PLANTATIONS PT. PENITI SUNGAI PURUN, \\ MEMPAWAH REGENCY
}

Bayu Saputra, Denah Suswati, dan Rini Hazriani

Program Studi Ilmu Tanah Fakultas Pertanian Universitas Tanjungpura, Pontianak Jln. Prof. Dr. Hadari Nawawi, Pontianak, 78124, Indonesia.

Email: bayu.saputra@gmail.com

\begin{abstract}
ABSTRAK
Kadar hara merupakan proses untuk mengetahui kandungan unsur hara yang ada didalam jaringan tanaman. Kadar hara diperoleh melalui survey lapangan dan analisis unsur hara di laboratorium. Penelitian ini bertujuan untuk mengetahui Kadar hara N, P dan K serta merekomendasi penggunaan hara $\mathrm{N}, \mathrm{P}$ dan $\mathrm{K}$ untuk tanaman kelapa sawit sehingga dapat meningkatkan produksi kelapa sawit. Penelitian ini dilakukan di PT. Peniti Sungai Purun Kabupaten Mempawah. Hasil Analisis menunjukkan bahwa kadar hara N, P dan K pada Blok G50 tergolong defisiensi sampai optimum, Blok H34 tergolong defisiensi sampai optimum, Blok I26 tergolong defisiensi sampai optimum, dan Blok J26 tergolong defisiensi sampai optimum. Pada masing-masing Blok di Rekomendasikan dosis pemupukan N, P dan K untuk blok G50 (1,73 kg urea/pohon/tahun, 1,50 kg Rock Phospate/pohon/tahun, dan 2,50 kg KCl/pohon/tahun). Blok H34 (3.00 kg urea/pohon/tahun, $3,50 \mathrm{~kg}$ Rock Phospate/pohon/tahun, dan 3,50 kg KCl/pohon/tahun). Blok I26 (1,73 kg urea/pohon/tahun, 1,50 kg Rock Phospate/pohon/tahun, dan 2,50 kg KCl/pohon/tahun). Blok J26 (3,00 $\mathrm{kg}$ urea/pohon/tahun, 3,50 kg Rock Phospate/pohon/tahun, dan $3.50 \mathrm{KCl} /$ pohon/tahun). Dosis rekomendasi digunakan untuk meningkatkan produksi tanaman Kelapa Sawit di PT. Peniti Sungai Purun.
\end{abstract}

Kata Kunci : Kadar Hara, Rekomendasi Pemupukan

\section{ABSTRACT}

Nutrient levels is the process to determine the present nutrient content in tissue plant. Nutrient levels obtained through field survey and nutrient analysis in the laboratory. This research aims to determine levels of $N, P$ and $K$ as well as recommend the use of $N, P$, and $K$ for oil palm plants so as to increase the production of palm oil. This research was conducted at PT. Peniti Sungai Purun, MempawahRegency. The analysis results showed that the levels of $N, P$, and $K$ on all blocks belonging to deficiency until optimum. In each block, the dose recommend of fertilizer $N, P$, and $K$ to block G5O (1,73 kg urea/tree/year, $1,50 \mathrm{~kg}$ Rock Phospate/tree/4 times/year, and 2,50 kg KCl/tree/year) Blocks H34 (3,00 kg urea/tree/year, 3,50 kg Rock Phospate/tree/year, and 3,50 kg KCl/tree/year). Block I26 (1,73 kg urea/tree/year, 1,50 kg Rock Phospate/tree/year, and 2,50 kg KCl/tree/year). Block J26 (3,00 $\mathrm{kg}$ urea/tree/year, 3,50 $\mathrm{kg}$ Rock Phospate/tree/ year, and 3,50 $\mathrm{kg} \mathrm{KCl/tree/year).} \mathrm{This} \mathrm{dosage}$ recommendations are used to increase the production of oil palm plants in PT. Peniti Sungai Purun.

Keywords : Nutrient levels, Recommendation of Fertilization . 


\section{PENDAHULUAN}

Tanaman kelapa sawit merupakan satu diantara tanaman perkebunan yang memerlukan input hara cukup tinggi, sehingga kebutuhan pupuk per hektar cukup besar, pemupukan menjadi faktor penting dalam upaya mencapai produktivitas yang tinggi, terutama dalam memenuhi ketersediaan hara. Unsur hara dari pupuk menjadi tambahan energi yang sangat diperlukan bagi pertumbuhan dan produktivitas kelapa sawit (Darmosarkoro et al., 2007). Tercapainya produksi tandan buah segar (TBS) yang optimal dan kualitas minyak yang baik merupakan tujuan dari pemupukan pada tanaman kelapa sawit. Kekurangan satu diantara unsur hara akan menyebabkan tanaman menunjukkan gejala defisiensi dan mengakibatkan terhambatnya pertumbuhan vegetatif serta penurunan produksi tanaman, disamping itu produktivitas tanaman kelapa sawit juga ditentukan oleh karakteristik lahan yang berbeda pada setiap wilayah pengembangannya. Menurut Rosmarkam dan Yuwono (2002), berdasarkan jumlah yang diperlukan, unsur hara dibagi menjadi 2 golongan yakni unsur hara makro dan unsur hara mikro. Unsur hara makro diperlukan tanaman dalam jumlah yang lebih besar dibandingkan dengan unsur hara mikro. Kadar $\mathrm{N}$ misalnya, dalam jaringan tanaman lebih besar dan kandungan hara juga berbeda - beda tergantung pada jenis hara, jenis tanaman, kesuburan tanah atau jenis tanah serta pengelolaan tanaman.

Tanah gambut diklasifikasikan berdasarkan berbagai sudut pandang yang berbeda, dari tingkat kematangan, kedalaman, kesuburan dan posisi pembentukannya. Ketersediaan hara bagi tanaman di tentukan oleh faktor - faktor yang mempengaruhi kemampuan tanah dalam mensuplai hara dan faktor - faktor yang mempengaruhi kemampuan tanaman untuk menggunakan unsur hara yang disediakan. Unsur Nitrogen (N) merupakan unsur yang sangat penting bagi pertumbuhan tanaman khususnya dalam pembentukan atau pertumbuhan bagian bagian vegetatif tanaman seperti daun, batang dan akar (Djajadirana, 2000). Unsur fosfor (P) dapat merangsang perkembangan perakaran terhadap pertumbuhan tanaman sedangkan terhadap produksi hasil tinggi dan memperbaiki kualitas hasil serta mempercepat masa kematangan (Nyakpa dkk., 1988). Unsur kalium (K) berperan dalam pembentukan protein dan karbohidrat serta meningkatkan kualitas biji atau buah (Djajadirana, 2000).

Penelitian ini bertujuan untuk Mengetahui Kadar hara N, P, dan K pada daun kelapa sawit di berbagai tingkat kematangan tanah gambut dan memberikan rekomendasi umum pemupukan $\mathrm{N}, \mathrm{P}$ dan $\mathrm{K}$ pada tanaman kelapa sawit.

\section{METODE PENELITIAN}

Penilitian ini dilaksanakan di lahan perkebunan kelapa sawit PT. Peniti Sungai Purun (PT. PSP) yang terletak di Kabupaten Mempawah, Provinsi Kalimantan Barat. Waktu penelitian berlangsung dari bulan November 2015 sampai dengan bulan April 2016 dimulai dari persiapan sampai dengan penyajian hasil.

Alat yang digunakan di lapangan berupa alat survey, dodos / egrek, pisau, gunting, kantong plastik, kertas label, alat tulis, dan alat dokumentasi, sedangkan alat yang digunakan di laboratorium Kimia dan Kesuburan Tanah yaitu : neraca analitik, tabung digestion, dan blok digestion, pengocok tabung, dispenser, alat destilasi atau Spektrofotometer, labu didih $250 \mathrm{ml}$, erlenmeyer100 ml, tabung reaksi dan Flamephotometer.

Pengambilaan sampel daun dilakukan menggunakan sistem grid, yaitu pengambilan sampel dengan melakukan penelusuran jalur dan sesuai dengan perencanan kerja yang telah dibuat. Sampel daun diambil anak daun nya pada pelepah ke 17 dan pengambilan sampel daun dilakukan berdasarkan tingkat kematangan gambut hemik dan gambut saprik sebanyak 6 titik sampel yang dikompositkan.

\section{HASIL DAN PEMBAHASAN}

\section{Kadar Nitrogen (N)}

Hasil anlisis N-Total pada jaringan daun kelapa sawit yang dilakukan dilaboratorium dapat dilihat pada Tabel 1 berikut ini : 
Tabel 1. Kadar Hara Nitrogen (N) Total pada Jaringan Daun Kelapa Sawit di Lokasi Penelitian.

\begin{tabular}{lll}
\hline Blok Sampel & N Total (\%) & \multicolumn{1}{c}{ Kriteria } \\
\hline G50 & 2,54 & Optimum \\
H34 & 2,15 & Defisiensi \\
I26 & 2,54 & Optimum \\
J26 & 2,54 & Optimum \\
\hline
\end{tabular}

Sumber: Hasil Analisis Laboratorium Kimia dan Kesuburan Tanah Faperta Untan, 2016.

Tabel 3 menunjukkan bahwa kandungan $\mathrm{N}$ total pada daun di semua blok tidak mencapai kriteria tinggi. Hal ini diduga disebabkan oleh curah hujan yang tinggi $(227,5 \mathrm{~mm} /$ tahun $)$ sehingga terjadinya pencucian hara $\mathrm{N}$, dan kriteria $\mathrm{pH}$ tanah di lokasi penelitian bersifat sangat masam. Hal ini sesuai dengan pendapat Hardjowigeno (2003) bahwa rendahnya kandungan $\mathrm{N}$ total disebabkan adanya pencucian yang diakibatkan oleh curah hujan yang tinggi dan adanya penguapan amoniak karena penguapan amoniak terjadi pada keadaan asam. Kehilangan $\mathrm{N}$ juga dapat dalam bentuk gas yang diakibatkan oleh kegiatan mikroba di dalam tanah, sehingga berpengaruh terhadap penyerapan hara nitrogen dalam bentuk $\mathrm{N}$ yang tersedia bagi tanaman, karena tanaman mengambil nitrogen dalam bentuk $\mathrm{NH}_{4}{ }^{+}$dan $\mathrm{NO}_{3}{ }^{-}$. Selain itu ketersediaan $\mathrm{N}$ juga dipengaruhi oleh C-organik tanah yang tergolong sangat tinggi di semua blok penanaman. Hal ini karena di lokasi penelitian merupakan tanah gambut yang belum terdekomposisi sempurna sehingga sebagian besar $\mathrm{N}$ masih dalam bentuk organik yang tidak tersedia bagi tanaman. Menurut Hanafiah (2005), di dalam tanah terdapat $99 \% \mathrm{~N}$ dalam bentuk organik, hanya $2-4 \%$ nya dimineralisasikan menjadi $\mathrm{N}$ anorganik $\left(\mathrm{NH}_{3}{ }^{+}\right)$ (amonifikasi) oleh berbagai mikroba heterotrof, kemudian sebagiannya mengalami nitrifikasi.

Kadar N total daun pada blok H34 termasuk dalam kriteria defesiensi, karena kurangnya pupuk yang diberikan yaitu urea 2,5 $\mathrm{kg} / \mathrm{ha} /$ tahun sedangkan berdasarkan rekomendasi kebutuhan pupuk pada blok H34 sebesar 3,0 kg urea/pohon/tahun sehingga hara yang diserap tanaman kurang (defisiensi), selain itu ketersediaan $\mathrm{N}$ tanah juga rendah karena tingkat kematangan hemik. Namun demikian pada blok J26 pemberian urea 2,5 $\mathrm{kg} / \mathrm{ha} /$ tahun sudah diserap dalam kriteria optimum walaupun rekomendasi dosis pemupukan urea sebesar 3,0 kg/pohon/tahun. Hal ini dimungkinkan karena pada blok J26 tingkat kematangan tanah nya saprik sehingga ketersediaan $\mathrm{N}$ tanah juga tinggi. Selain itu pada blok J26 kedalaman air dalam saluran drainase termasuk kriteria sedang yaitu $56 \mathrm{~cm}$ dari permukaan tanah, sehingga memungkinkan mikroorganisme berkembang pesat sehingga proses dekomposisi berjalan lancar akibatnya ketersediaan $\mathrm{N}$ total tanah menjadi meningkat. Menurut Yoshida (1981), pemberian nitrogen di bawah optimal menyebabkan pertumbuhan akar terhambat, ditinjau dari berbagai hara nitrogen yang paling mendapat perhatian. Hal ini disebabkan jumlah nitrogen dalam tanah sedikit sedangkan tanaman memerlukan hara yang sangat banyak. Menurut Soepardi (1983), kerugian yang disebabkan oleh kekurangan $\mathrm{N}$ yaitu daun tanaman menjadi kuning atau hijau kekuningan dan cenderung cepat rontok. Kekurangan nitrogen akan mengakibatkan kandungan protein pada tanaman menjadi sangat sedikit, sehingga karbohidrat yang diendapkan menjadi semakin banyak dan menyebabkan sel-sel vegetatif tanaman menebal.

\section{Kadar Fosfor (P)}

Hasil analisis daun menunjukkan bahwa kandungan $\mathrm{P}$ pada daun di semua Blok penelitian termasuk dalam kategori defisiensi yang dapat dilihat pada Tabel 2 .

Tabel 2. Kadar Hara Fosfor (P) Total pada Jaringan Daun Kelapa Sawit di Lokasi Penelitian

\begin{tabular}{lll}
\hline Blok Sampel & $\mathrm{P}(\%)$ & Kriteria \\
\hline G50 & 0,11 & Defisiensi \\
H34 & 0,10 & Defisiensi \\
I26 & 0,10 & Defisiensi \\
J26 & 0,13 & Defisiensi \\
\hline
\end{tabular}

Sumber: Hasil Analisis Laboratorium Kimia dan Kesuburan Tanah Faperta Untan, 2016

Tabel 5 menunjukkan bahwa kandungan $P$ total di daun tergolong defisiensi, berdasarkan kriteria penilaian menurut Uexkull, and Fairhurts, (1991) dalam Syahfitri 
(2009). Ketersediaan $P$ yang rendah diduga karena fosfor bersifat mobil atau mudah bergerak antar jaringan tanaman sehingga kadar P di daun defisiensi. Menurut Morard dalam Rosmarkam (2002) setelah diserap oleh akar, P mula - mula diangkut ke daun muda, kemudian dipindahkan ke daun yang lebih tua.

Selain itu, aplikasi pemupukan $\mathrm{P}$ dengan takaran $1,5 \mathrm{~kg} /$ pohon/tahun dalam bentuk rock phospate lebih rendah dari rekomendasi yaitu $1,5-3,5 \mathrm{~kg} /$ pohon/tahun (Tabel 7), sehingga mempengaruhi rendahnya kadar hara $\mathrm{P}$ yang terdapat pada daun tanaman kelapa sawit karena $\mathrm{pH}$ tanah gambut di lokasi penelitian bersifat sangat masam dengan $\mathrm{pH}$ antara 3,06 3,64 sehingga $\mathrm{P}$ yang ditambahkan ke dalam tanah menjadi tidak tersedia. Faktor yang mempengaruhi ketersediaan $\mathrm{P}$ tanah antara lain $\mathrm{C}$-organik tinggi sehingga proses dekomposisi terhambat akibatnya ketersediaan $\mathrm{P}$ rendah sehingga serapan $\mathrm{P}$ juga rendah. Menurut Winarso (2005) unsur hara $P$ sangat berperan dalam metabolisme, sehingga dapat mengakibatkan penurunan proses metabolisme yang meliputi terhambatnya pertumbuhan dan fotosintesa. Selain itu $P$ juga membantu meningkatkan kualitas buah dan meningkatkan daya tahan terhadap penyakit yang akhirnya meningkatkan kualitas hasil panen. Upaya mencegah kekurangan hara $\mathrm{P}$ pada tanah gambut adalah dengan penggunaan pupuk yang tersedianya lambat.

\section{Kadar Kalium (K)}

Hasil analisis daun di laboratorium menunjukkan bahwa kandungan $\mathrm{K}$ total daun pada blok G50, H34, dan J26 termasuk dalam kategori optimum, blok I26 termasuk dalam kategori defisiensi. Dalam analisis $\mathrm{K}$ menggunakan metode ekstraksi HCL 1N. Hasil analisis dapat dilihat pada Tabel 3.

Tabel 3. Kadar Hara Kalium (K) Total pada Jaringan Daun Kelapa Sawit di Lokasi Penelitian

\begin{tabular}{lll}
\hline Blok Sampel & K $(\%)$ & Kriteria \\
\hline G50 & 1,25 & Optimum \\
H34 & 1,00 & Optimum \\
I26 & 0,90 & Defesiensi \\
J26 & 1,20 & Optimum \\
\hline
\end{tabular}

Sumber: Hasil Analisis Laboratorium Kimia dan Kesuburan Tanah Faperta Untan, 2016
Tabel 5 menunjukkan bahwa kandungan $\mathrm{K}$ total di daun pada lokasi penelitian di blok G50, H34 dan J26 tergolong optimum. Penggolongan ini berdasarkan kriteria penilaian kadar hara daun menurut Uexkull and Fairhurts (1991) dalam Syahfitri (2009). $\mathrm{Hal}$ ini menunjukkan bahwa pemberian hara $\mathrm{K}$ dengan takaran $3 \mathrm{~kg} /$ pohon/tahun sesuai dengan dosis anjuran menurut Pahan (2013) pemupukan kelapa sawit Tanaman Menghasilkan (TM) umur 3 - 5 tahun sebesar $2,5 \mathrm{~kg} /$ pohon/tahun dan umur $6-15$ tahun sebesar 3,5 kg/pohon/tahun.

Selain itu pemberian pupuk $\mathrm{K}$ juga sudah sesuai dengan rekomendasi dosis pemupupukan yaitu berkisar antara 2,5 - 3,5 $\mathrm{kg} /$ pohon/tahun, sehingga kadar hara $\mathrm{K}$ menjadi optimum. Kalium merupakan hara yang sangat penting pada saat proses inisiasi atau pembungaan tanaman kelapa sawit karena akan berpengaruh terhadap jumlah dan ukuran tandan buah kelapa sawit. Kadar hara $\mathrm{K}$ di blok I26 termasuk defisiensi, hal ini dimungkinkan karena ketersediaan hara $\mathrm{K}$ tanah juga rendah sehingga kadar hara $\mathrm{K}$ pada tanaman juga rendah (defisiensi).

Kalium di dalam tanah dapat dibedakan menjadi tidak tersedia bagi tanaman, tersedia tapi terhambat (Hardjowigeno 1998). Kebutuhan tanaman akan unsur kalium cukup tinggi, apabila kalium tersedia dalam jumlah yang terbatas maka gejala kekurangan $\mathrm{K}$ akan kelihatan pada tanaman. Banyak atau sedikitnya kadar kalium di dalam jaringan daun kelapa sawit pada sampel penelitian sangat ditentukan oleh banyak atau sedikitnya kalium yang diserap oleh akar dan terangkut di dalam daun.

\section{Kadar Air Lapangan}

Tabel 4. Kadar Air Lapangan

\begin{tabular}{cccc}
\hline NO & $\begin{array}{c}\text { Blok } \\
\text { Sampel }\end{array}$ & $\begin{array}{c}\text { Kadar Air } \\
(\%)\end{array}$ & $\begin{array}{c}\text { Tingkat Kematangan } \\
(\%)\end{array}$ \\
\hline 1 & G50 & 546,82 & Hemik \\
2 & H34 & 485,94 & Hemik \\
3 & I26 & 364,38 & Saprik \\
4 & J26 & 440,92 & Saprik \\
\hline
\end{tabular}

Sumber: Hasil Analisis Laboratorium Kimia dan Kesuburan Tanah Faperta Untan, 2016 
Identifikasi tingkat kematangan gambut dilakukan di laboratorium dengan analisis kadar air, berdasarkan kriteria penilaian menurut Notohadiprawiro (1983) tingkat kematangan Fibrik memiliki Kadar Air Maksimum (KAM) 850 - >3.000\%, Hemik memiliki Kadar Air Maksimum (KAM) 450 $850 \%$, dan Saprik memiliki Kadar Air Maksimum (KAM) $<450 \%$. Hasil penilitian di Blok G50 dan H34 tingkat kematangannya hemik karena kadar air maksimumnya diantara 450 - 850\% dan di Blok I26 dan J26 tergolong saprik karena kadar air maksimumnya kurang dari $450 \%$.

\section{Rekomendasi Dosis Pemupukan}

Lokasi penelitian memiliki kadar hara nitrogen pada kriteria defisiensi sampai optimum, fosfor pada kriteria defisiensi, sedangkan kalium pada kriteria defisiensi samapai optimum, karena itu diperlukan usahausaha untuk meningkatkan ketersediaan unsur- unsur hara yang mempunyai peranan terhadap kesuburan tanah dan tanaman melalui pemupukan N, P dan K. Strategi dalam penyusunan rekomendasi pemupukan adalah memberikan unsur hara (dosis pupuk) yang mencukupi dan seimbang pada tanaman sehingga memungkinkan dicapainya produktifitas yang optimum.

Berdasarkan analisis jaringan daun untuk perhitungan rekomendasi pupuk distribusi biomassa dan unsur hara pada setiap pokok kelapa sawit menurut $\mathrm{Ng}$ and Thamboo 1967. Biomassa daun yaitu $186,76 \mathrm{~kg}$, unsur hara $\mathrm{N}(1,44 \mathrm{~kg}), \mathrm{P}(0,32 \mathrm{~kg})$, dan $\mathrm{K}(2,64 \mathrm{~kg})$. Dosis pupuk yang direkomendasikan untuk tanaman kelapa sawit dapat dilihat pada Tabel 7 dan rekomendasi dosis pupuk berdasarkan kadar hara jaringan tanaman menurut publikasi Ollagnier dan Ochs (1982); Suwandi et al. (1989); Suwandi dan Chan (1989); Siahaan et al. (1990); Siahaan et al. (1991) dalam Pahan (2013).

Tabel 5. Rekomendasi Dosis Pemupukan

\begin{tabular}{llcccc}
\hline NO & Jenis Pupuk & \multicolumn{4}{c}{ Blok sampel (kg/pohon/tahun) } \\
& & G 50 & H 34 & I 26 & J 26 \\
\hline 1 & Urea & 1,73 & 3,00 & 1,73 & 3,00 \\
2 & Rock Phospate & 1,50 & 3,50 & 1,50 & 3,50 \\
3 & KCL & 2,50 & 3,50 & 2,50 & 3,50 \\
\hline
\end{tabular}

Sumber : Perhitungan Kebutuhan Pupuk Berdasarkan Data Hasil Analisis Laboratorium

\section{SIMPULAN}

1. Analisis kadar Nitrogen diperoleh kandungan $\mathrm{N}$ total daun pada Blok H34 termasuk dalam kategori defisiensi dan di Blok G50, Blok I26, dan Blok J26 termasuk dalam kategori optimum.

2. Analisis kadar hara Fospor menunjukkan bahwa kandungan $\mathrm{P}$ total daun pada semua Blok penelitian termasuk dalam kategori defisiensi.

3. Analisis kadar Kalium menunjukkan bahwa kandungan $\mathrm{K}$ total daun termasuk dalam kategori optimum.

4. Rekomendasi pupuk N, P, dan K untuk Blok G-50 (Urea 1,73 kg/pohon/tahun, Rock Phospate 1,50 kg/pohon/tahun, KCL $2,50 \mathrm{~kg} /$ pohon/tahun), Blok H-34 (Urea 3,00 kg/pohon/tahun, Rock Phospate 3,50 $\mathrm{kg} /$ pohon/tahun, $\quad$ KCL $\quad 3,50$ $\mathrm{kg} /$ pohon/tahun), Blok I-26 (Urea 1,73 kg/pohon/tahun, Rock Phospate 1,50 $\mathrm{kg} /$ pohon/tahun, KCL 2,50 $\mathrm{kg} /$ pohon/tahun) dan Blok J-26 (Urea 3,00 $\mathrm{kg} /$ pohon/tahun, Rock Phospate 3,50 $\mathrm{kg} /$ pohon/tahun, $\quad \mathrm{KCL} \quad 3,50$ $\mathrm{kg} /$ pohon/tahun).

\section{DAFTAR PUSTAKA}

Darmosarkoro,W.,Sutarta,S.E dan Winarna. 2007. Lahan dan Pemupukan Kelapa

Djajadirana, S. 2000. Kamus Dasar Agronomi. Murai Kencana : Jakarta

Hanafiah, K, A, 2005. Dasar - Dasar Ilmu Tanah. PT. Raja Grafindo Persada. Jakarta.

Hardjowigeno. 1998. Klasifikasi Tanah dan Pedogenesis, Akademi Pressindo: Jakarta. 
Hardjowigeno. 2003. Klasifikasi Tanah dan Pedogenesis, Akademika Pressindo: Jakarta.

Nyakpa, M. Yusuf, A. M. Lubis, Mamat A.P., A.G. Amrah, Ali Munawar, Go Ban Hong, N. Hakim. 1988. Kesuburan Tanah. Angkasa. Universitas Lampung. Lampung.

Ng, S.K. and Thamboo, S. 1967. Nutrient contents of oil palms in Malaya. I. Nutrients required for reproduction: Fruit bunches and male inflorescence. The Malaysian Agricultural

Pahan, Iyung. 2013. Panduan Lengkap Kelapa Sawit Manajemen Agribisnis dari Hulu hingga Hilir. Penebar Swadaya : Jakarta.

Rosmarkam. A, dan Yuwono, W. N. 2002. Ilmu Kesuburan Tanah. Kanisius : Yogyakarta.
Soepardi , G. 1983. Sifat dan Ciri Tanah. Jurusan Ilmu- Ilmu Tanah, Fakultas Pertanian, IPB. Bogor

Syahfitri. M.M. 2009. Analisis Unsur Hara Fosfor (P) Pada Daun Kelapa Sawit Secara Spektrofotometri Di Pusat Penelitian Kelapa Sawit (PPKS) Medan. Universitas Sumatera Utara

Tejoyuwono, N. 1983. Selidik Cepat Ciri Tanah di Lapangan. Jurusan Ilmu Tanah, Fakultas Pertanian Universitas Gadjah Mada.

Winarso, S., 2005. Kesuburan Tanah Dasar Kesehatan dan Kualitas Tanaman, Gava Media, Jogyakarta.

Yoshida, A., and S.Yoshida. 1981. Nutritional Disorder of Rice Plant in Asia. Int. Rice Res. Int. Techology Bulletin. 